\title{
Educational differences in cigarette smoking among adult population in Estonia, 1990-2010: does the trend fit the model of tobacco epidemic?
}

Kersti Pärna ${ }^{1 *}$, Mari-Liis Pürjer ${ }^{1,2}$, Inge Ringmets ${ }^{1}$ and Mare Tekkel ${ }^{3}$

\begin{abstract}
Background: In developed countries, smoking spreads through society like an epidemic in which adults from higher socioeconomic groups are the first to adopt and earlier to quit smoking, and in which exists a lag in adoption of smoking between men and women.

The objective of this study was to describe trends in daily and occasional smoking, to investigate association between smoking status and education, and to examine if the associations in 1990-2010 in Estonia fit the pattern predicted by the model of tobacco epidemic.
\end{abstract}

Methods: The study was based on a 20-64-year-old subsample $(n=18740)$ of nationally representative postal cross-sectional surveys conducted every second year in Estonia during 1990-2010. Cigarette smoking and education were examined. $x^{2}$ test for trend was used to determine daily and occasional smoking trends over study years. Multinomial logistic regression model was used to test educational differences in daily and occasional smoking for every study year. Adjusted relative risk ratios (RRRs) with 95\% confidence intervals were calculated.

Results: In 1990-2010, daily smoking varied largely between genders showing decreasing trend among men, but not among women. In 2010, one third of men and one fifth of women were daily smokers. Daily smoking was not clearly associated with education among men in 1990-1994 and among women in 1990-2000. Men revealed inverse relationship between daily smoking and education since 1996, but women since 2002. In 2010, compared to men and women with higher education, relative risk ratio of daily smoking was $2.92(95 \% \mathrm{Cl}=2.01-4.25)$ among men and $2.29(95 \% \mathrm{Cl}=1.65-3.17)$ among women with secondary education, but 4.98 (95\% Cl 3.12-7.94) among men and $6.62(95 \% \mathrm{Cl}=4.07-10.76)$ among women with basic education.

In 1990-2010, occasional smoking was stable and similar (varying between 7-10\%) among men and women, no association with education was found.

Conclusions: Daily smoking patterns in Estonia fit the model of tobacco epidemic in developed countries. Educational differences in daily smoking highlight the importance of addressing smoking behaviour in the general population by educational subgroups in Estonia.

Keywords: Daily smoking, Occasional smoking, Adults, Education, Tobacco epidemic, Estonia

\footnotetext{
*Correspondence: kersti.parna@ut.ee

'Department of Public Health, University of Tartu, Ravila 19, 50411 Tartu,

Estonia

Full list of author information is available at the end of the article
} 


\section{Background}

Socioeconomic inequalities in health have been studied extensively and it has been found that smoking is associated with socioeconomic position of adults [1]. In developed countries smoking prevalence is generally higher among adults from the lower socioeconomic group [2-4], while in developing countries this situation is reversed [5]. Education is often used as an indicator of socioeconomic position since it typically precedes work and income, and reflects knowledge and skills that are important for making health behaviour choices [6].

Many authors have described the lag in the adoption of smoking between higher and lower socioeconomic groups, and the lag in adoption between men and women. These aspects are described in the spread of the tobacco epidemic in societies which has followed four stages [2,5,7-10]. In the first stage, prevalence of smoking is low, and mainly a habit of higher socioeconomic groups. In the second stage, the prevalence of smoking among men increases and is similar in different socioeconomic groups. The spread of smoking among women lags 1020 years behind that of men, and the habit is adopted first by women in the higher socioeconomic group. In the third stage, the prevalence of smoking among men decreases, as men begin to quit smoking, especially those in the higher socioeconomic group while the prevalence among women reaches a ceiling. At the end of this stage a reduction in smoking begins to be observed among women. Finally in the fourth stage, the prevalence of smoking slowly decreases both among men and women, and smoking becomes a habit concentrated mainly in the lower socioeconomic groups [2,5,7-10].

Since regaining independence from the Soviet Union in 1991, Estonia has experienced political reforms and economic changes, which, among other things, have had a strong effect on health behaviour. Smoking in Estonia has historically been similar to other postSoviet countries where the prevalence were considerably higher for male than for female [11]. In Estonia, smoking has been analysed from different aspects [12-14]. Socioeconomic differences in smoking were analysed in 1996 and 2006 [15,16]. No in-depth analysis of long-term trends by socioeconomic position was performed in Estonia. In order to prevent and reduce tobacco consumption effectively, it is important to have knowledge of trends of smoking and socioeconomic differences in smoking in the country concerned [17-19].

The objectives of this study were to describe trends of daily and occasional smoking, to investigate association between smoking status and education, and to examine if the associations in 1990-2010 in Estonia fit the pattern predicted by the model of tobacco epidemic.

\section{Methods}

Data

The present study was based on the cross-sectional nationally representative postal survey of Health Behaviour among Estonian Adult Population, which is the part of the Finbalt Monitor project, conducted among 16-64year-old adults every second year since 1990. The surveys were approved by the Tallinn Medical Research Ethics Committee. Full details of the survey methodology by the study year have been described in published reports [20-30].

\section{Sample and response rate}

A stratified (by age, gender, and place of residence) random sample from the Estonian population aged 16-64 was ordered from the Population Register for each survey year. Initial sample size in the period 1990-2002 was 1500-2000, from the year 2004 it was 5000 persons (Table 1). The crude response rate was $72.3 \%$ in 1990 and $60.5 \%$ in 2010 being only once less than $60 \%$ (57.3\% in 2006). The adjusted response rates (excluding the persons who had wrong address, left Estonia or were dead) were available only for the last four study years.

This paper studied the population aged 20-64. In 2004-2010, the crude and adjusted response rates for this age group were comparable with response rates of initial sample (Table 1). No data was available to calculate response rates for 20-64-year-olds in earlier study years.

\section{Variables}

Smoking status was determined by combining answers to two questions about current and past smoking. In 19902002, the questionnaire included filter question "Have you ever smoked?" (yes; no) and question about current smoking "Do you currently smoke?" (yes, daily; yes, occasionally; not at all). Since 2004 two previous questions were combined "Have you ever smoked?" (no; yes, currently every day; yes, currently occasionally; yes, but I have quit). The responses to these questions served as a basis for categorising respondents as daily smokers, occasional smokers, and non-smokers (ex- and never smokers).

Education was based on the highest completed educational level and was designated as follows: basic (less than 10 school years), secondary (10-14 years), and higher education (15+ years).

\section{Statistical analysis}

Data was analysed using statistical package Stata 11.2. Since previous studies have shown that smoking prevalence differs between men and women [3,31,32] and since this was one requirement for analysing smoking 
Table 1 Number and response rates for the initial sample (16-64-year-olds) and response rate for the sample used in this study (20-64-year-olds) by study year in Estonia, 1990-2010

\begin{tabular}{|c|c|c|c|c|c|}
\hline \multirow[t]{3}{*}{$\begin{array}{l}\text { Study } \\
\text { year }\end{array}$} & \multicolumn{3}{|c|}{$\begin{array}{c}\text { Initial survey sample of } \\
16-64 \text {-year-olds }\end{array}$} & \multirow{2}{*}{\multicolumn{2}{|c|}{$\begin{array}{c}\text { Study sample of } \\
\text { 20-64-year-olds } \\
\text { Response rate }\end{array}$}} \\
\hline & \multirow{2}{*}{$\begin{array}{l}\text { Sample } \\
\text { size* }^{*}\end{array}$} & \multicolumn{2}{|c|}{ Response rate } & & \\
\hline & & Crude & Adjusted & Crude & Adjusted \\
\hline 1990 & 1500 & 72.3 & - & - & - \\
\hline 1992 & 1500 & 63.2 & - & - & - \\
\hline 1994 & 1500 & 82.9 & - & - & - \\
\hline 1996 & 2000 & 75.4 & - & - & - \\
\hline 1998 & 2000 & 66.1 & - & - & - \\
\hline 2000 & 2000 & 68.8 & - & - & - \\
\hline 2002 & 2000 & 66.9 & - & - & - \\
\hline 2004 & 5000 & 61.5 & 63.4 & 60.1 & 62.8 \\
\hline 2006 & 5000 & 57.3 & 59.2 & 56.6 & 58.5 \\
\hline 2008 & 5000 & 60.1 & 62.2 & 59.7 & 61.9 \\
\hline 2010 & 5000 & 60.5 & 62.3 & 60.7 & 62.6 \\
\hline
\end{tabular}

*Number of persons to whom the questionnaire was sent.

trends in relation to the model of tobacco epidemic [5], the data were analysed separately for both genders.

Prevalence of daily and occasional smoking was calculated for each study year. The directly age-standardised percentage prevalences of daily and occasional smoking were calculated using the European standard population [33]. $x^{2}$ test for trend was used to determine trends in daily and occasional smoking over study years.

Multinomial logistic regression model was applied to assess the association between smoking status and education for every survey year. For that, smoking status (daily smoking, occasional smoking, non-smoking) was used as a dependent variable and relative risks of daily smoking $v s$ non-smoking and occasional smoking $v s$ non-smoking were calculated. Education (higher, secondary, basic) was used as an explanatory variable and relative risk ratios (RRRs) with 95\% confidence intervals (CI), as the measure of outcome, were calculated to compare relative risks for daily and occasional smoking in different educational groups (secondary vs higher education, basic vs higher education). The estimates were adjusted for age, ethnicity (Estonian, non-Estonian), marital status (single, married or cohabiting, divorced or separated, widowed), employment status (employed, unemployed, homemaker, student or recruited, retired).

Questionnaires which lacked information about smoking were excluded from the analysis. A total of 18740 questionnaires (7949 men and 10791 women) were used in the study (Table 2). Questionnaires with missing information concerning education $(n=151)$ were excluded from the analysis of smoking by education.
Table 2 Study sample of 20-64-year-old men and women by study year in Estonia, 1990-2010

\begin{tabular}{lrrrrrr}
\hline \multirow{2}{*}{$\begin{array}{c}\text { Study } \\
\text { year }\end{array}$} & \multicolumn{2}{c}{ Men } & & \multicolumn{2}{c}{ Women } & Total \\
\cline { 2 - 3 } \cline { 5 - 6 } & $\mathbf{N}$ & $\%$ & & $\mathbf{N}$ & $\%$ & $\mathbf{N}$ \\
\hline 1990 & 439 & 43.7 & & 566 & 56.3 & 1005 \\
1992 & 422 & 47.3 & & 470 & 52.7 & 892 \\
1994 & 508 & 43.0 & 673 & 57.0 & 1181 \\
1996 & 611 & 44.2 & & 771 & 55.8 & 1382 \\
1998 & 502 & 44.5 & 627 & 55.5 & 1129 \\
2000 & 467 & 41.3 & 663 & 58.7 & 1130 \\
2002 & 448 & 41.5 & 631 & 58.5 & 1079 \\
2004 & 1168 & 43.8 & 1500 & 56.2 & 2668 \\
2006 & 1030 & 39.4 & 1584 & 60.6 & 2614 \\
2008 & 1175 & 42.2 & 1607 & 57.8 & 2782 \\
2010 & 1179 & 41.0 & 1699 & 59.0 & 2878 \\
Total & 7949 & 42.4 & 10791 & 57.6 & 18740 \\
\hline
\end{tabular}

\section{Results}

Prevalence of daily smoking varied markedly between genders during the whole study period (Figure 1). In $1990,47.4 \%$ of men and $15.2 \%$ of women were daily smokers. Age-standardised prevalence (European population) of daily smoking was $47.0 \%$ and $16.7 \%$, respectively. In $2010,37.9 \%$ of men and $19.0 \%$ of women were daily smokers. Age-standardised prevalence of daily smoking was $38.1 \%$ and $19.5 \%$, respectively. The years 1990-2010 showed decreasing trend in daily smoking among men $(\mathrm{p}<0.01)$. During the study period, daily smoking among women increased slightly but this trend was not statistically significant.

Occasional smoking was similar and stable among men and women during the whole study period (Figure 1). In 1990, 8.4\% of men and 9.4\% of women (age-standardised prevalence $10.3 \%$ and $11.0 \%$, respectively), and in 2010, $8.8 \%$ of men and $7.2 \%$ of women (age-standardised prevalence $9.4 \%$ and $7.8 \%$, respectively) were occasional smokers.

During the study period, prevalence of daily smoking decreased significantly from $48.7 \%$ to $27.1 \%(\mathrm{p}<0.01)$ among men with higher and from $55.5 \%$ to $48.2 \%$ ( $\mathrm{p}<$ 0.01) among men with secondary education (Figure 2). Daily smoking among men with basic education decreased slightly from $62.5 \%$ to $56.6 \%$, but the changes were not statistically significant.

In 1990-2010, the prevalence of daily smoking decreased significantly from $21.2 \%$ to $17.4 \%(\mathrm{p}<0.01)$ among women with higher education, but doubled from $19.7 \%$ to $40.0 \%$ $(\mathrm{p}<0.01)$ among women with basic education (Figure 2). There were no significant changes in daily smoking among women with secondary education in 1990-2010. No 


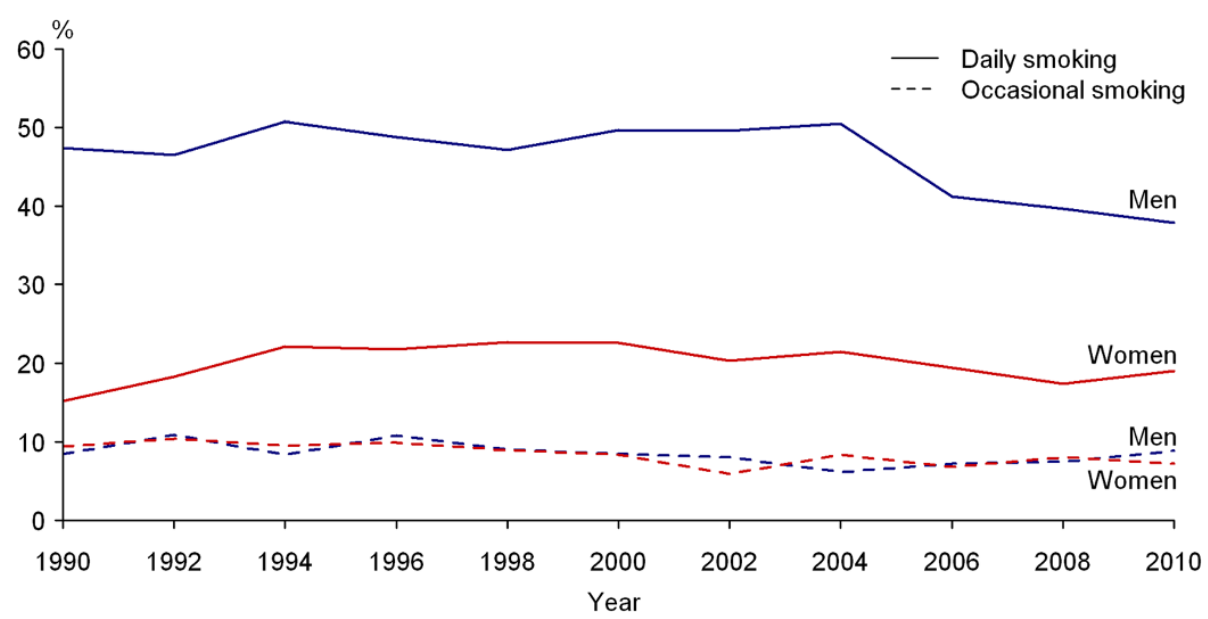

Figure 1 Trends in prevalence of daily and occasional smoking among 20-64-year-olds. Prevalence of daily smoking varied markedly between genders during the whole study period. In 1990, 47.4\% of men and 15.2\% of women were daily smokers. In 2010, 37.9\% of men and $19.0 \%$ of women were daily smokers. The years $1990-2010$ showed decreasing trend in daily smoking among men ( $p<0.01$ ). During the study period, daily smoking among women increased slightly, but this trend was not statistically significant. Occasional smoking was similar and stable among men and women during the whole study period. In 1990, 8.4\% of men and $9.4 \%$ of women and in $2010,8.8 \%$ of men and $7.2 \%$ of women were occasional smokers.

significant trends over time were established in occasional smoking by education among men and women.

Using adjusted multinomial regression model, no clear association between daily smoking and education was found among men in 1990-1994 and among women in 1990-2000 (Figure 3). Men revealed inverse relationship between daily smoking and educational level since 1996, but women since 2002. Compared to men with higher education, relative risk of daily smoking ( $v s$ nonsmoking) was $3.72(95 \% \mathrm{CI}=2.45-6.35)$ times higher among men with secondary education and 5.44 (95\% CI = 2.78-10.65) times higher among men with basic education in 1996. Respective RRRs were $2.92(95 \% \mathrm{CI}=2.01-4.25)$ and 4.98 (95\% CI 3.12-7.94 in 2010) among men in 2010. Compared to women with higher education, relative risk of daily smoking ( $v s$ non-smoking) was 1.88 (95\% CI = 1.07-3.31) times higher among women with secondary education and 3.67 times higher (95\% CI $=1.66-8.12$ ) among women with basic education in 2002. Respective RRRs were $2.29(95 \% \mathrm{CI}=1.65-3.17)$ and 6.62 (95\% CI 4.07-10.76) among women in 2010.

In 1990-2010, no association between occasional smoking and education was found among men and women (data not shown).

\section{Discussion}

This study focused on educational differences in daily and occasional smoking in 1990-2010 in Estonia. The main findings from the study were, first, that daily smoking varied largely between genders showing decreasing trend among men, but not among women. Second, the study showed that education plays an important role for daily smoking. Third, patterns of daily smoking in Estonia fit the model of tobacco epidemic in developed countries.

The survey of Health Behaviour among Estonian Adult Population present an outstanding opportunity to analyse smoking trends during two decades in Estonia because of the same study design and methodology across the whole study period.

One limitation of the survey is the use of self-reported data on smoking, which may result in underreporting of smoking. If underreporting of smoking differed by education status, the patterns found in this study may be biased. In general, self-reported smoking prevalence has been considered a valid indicator of the actual smoking status [34,35], especially in epidemiological studies. Also, studies investigating under-reporting in relation to education have shown inconsistent results [36,37]. Another limitation could be the use of education as the only indicator of socioeconomic status. On the one hand, education is skewed toward lower levels among young people, since they have not yet completed their highest level of education. On the other hand, education is being available for both men and women, including those who are currently outside employment and education usually precedes work and income. As relative risk ratios in the model were adjusted for employment status, age, ethnicity and marital status, this limitation is not likely to have affected our results. Unfortunately it was not possible to use income in this study as the question concerning the income was added to the questionnaire since 1996 only. Finally, one limitation stems from the fact that the study sample was significantly smaller until 

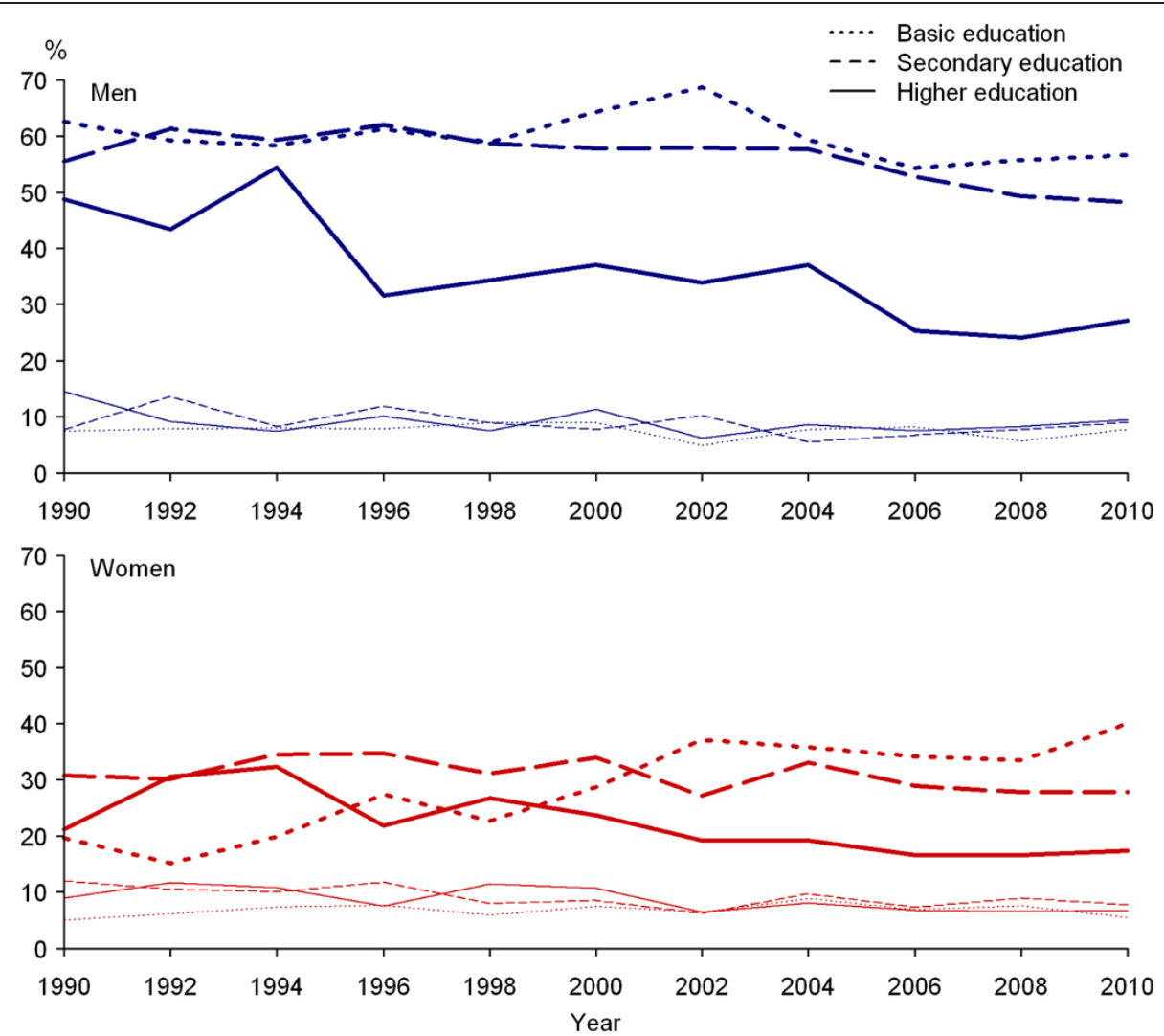

Figure 2 Trends in daily (thick lines) and occasional (thin lines) smoking by education among 20-64 year-olds. Compared to lower educated men, daily smoking was less common among men with higher education in 1990-2010, but among women since 2000. During the study period, prevalence of daily smoking decreased significantly from $48.7 \%$ to $27.1 \%(p<0.01)$ among men with higher and from $55.5 \%$ to $48.2 \%$ ( $p<0.01$ ) among men with secondary education. Daily smoking among men with basic education decreased slightly from $62.5 \%$ to $56.6 \%$, but the changes were not statistically significant. During the study period, the prevalence of daily smoking decreased significantly from $21.2 \%$ to $17.4 \%$ ( $p<0.01)$ among women with higher education and doubled from $19.7 \%$ to $40.0 \%(p<0.01)$ ] among women with basic education. There were no significant changes in daily smoking among women with secondary education in 1990-2010. No significant trends over time were established in occasional smoking by education among men and women.

2002 which probably reduced the power to detect significant differences. Despite these caveats, several inferences can be drawn.

The results of this study demonstrated that in 2010 one third of men and one fifth of women were daily smokers in Estonia. Notably higher smoking prevalence among men is common in the former Soviet countries [38], meanwhile in the most Scandinavian countries the smoking prevalence between genders has been diminished $[31,39]$. For example, $22 \%$ of men and $15 \%$ of women were daily smokers in Finland in 2011 [40]. Compared to the first study year, the prevalence of daily smoking among men decreased significantly, but slightly increased among women by 2010 . The same trends in smoking among women were seen in other Baltic and former Soviet countries [11,38]. At the same time, the prevalence of smoking among women in Finland has long been steady at the level of the mid-1980s, but has shown a slight downward turn in recent years [40].
In the current study, trends in smoking by education showed that education plays an important role for daily smoking. Daily smoking started to decrease among men with higher education since 1994, these aspects showed spread of changes of daily smoking by education among women behind that of men. During the study years, the difference in daily smoking prevalence between adults with lower and higher education increased. At the same time, no educational changes in trends of occasional smoking were found. While prevalence of daily smoking among men and women with higher education decreased significantly, the same indicator among men with basic education has remained more or less on the same level but it has doubled among women during the whole study period. More educated men and women have shown decreasing trends in smoking compared with the less educated groups in many European countries (e.g. Denmark, Sweden) [3]. Main reasons why it could be harder to quit smoking among adults with lower education are that they 


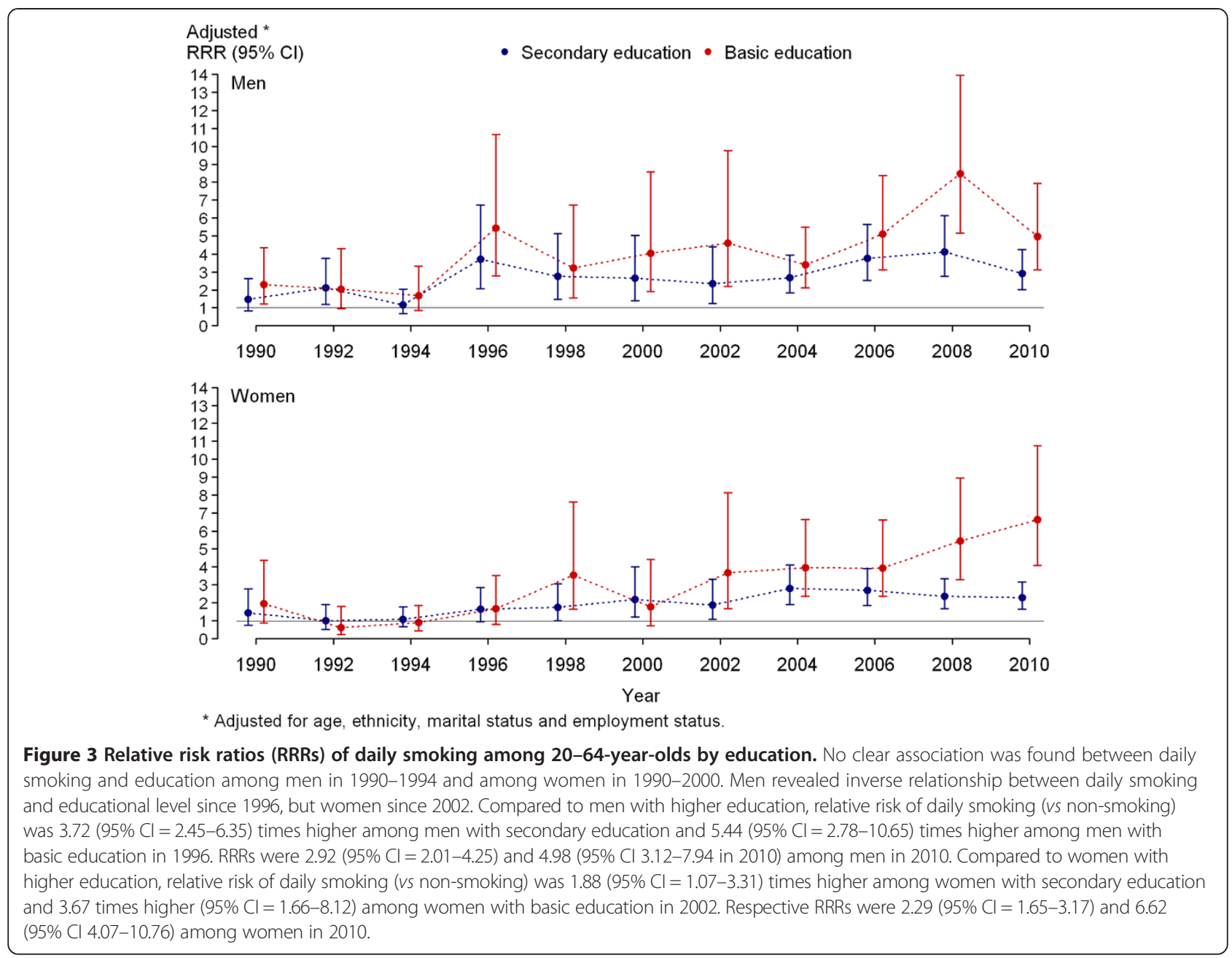

may lack motivation, social support, enough resources to purchase nicotine replacement therapy products and also different psychological factors such as low self-esteem and susceptibility to pressure and advertising by tobacco industries [41]. Conversely, less educated men and women had greater declines in smoking than more educated adults in United Kingdom, which might be related to the pricing policy, free access to smoking cessation therapies, and restrictions on advertising of tobacco products in the country concerned [3].

Comparing the results of current study with the cigarette epidemic model, the trends in daily smoking in different educational groups in Estonia were following the same trend and smoking among women lagged that behind of men. In the beginning of the study period, daily smoking was not associated with education among men and women. Inverse relationship between smoking and education appeared among men since 1996, but among women since 2002. The similar results were found in Estonian Health Interview Surveys in 1996 and 2006. In 1996, odds to smoke daily was lower among men with higher education, but this was not the case for women [15]. In 2006, smoking was less common among men and women with higher education [16]. However, there were only two time points in Estonian Health Interview Survey, this was interview based survey and the age group was not exactly the same like in this study.

Thus, in 1990, Estonia was in the beginning of third stage of cigarette smoking model, where there were no educational differences in daily smoking among men and women. In 2010, Estonia was fitting the middle of third stage of the cigarette smoking model, where smoking was lower among both genders with higher education, but there existed lag in adoption of this between men and women. According to the educational inequalities in smoking of different countries in Europe, daily smoking in Estonia was higher among adults with lower education like in Denmark, Finland, UK, Ireland, Germany, but not like in Austria, Italy, Spain, Greece and Portugal where it was more prevalent among women with higher education [4]. 


\section{Conclusions}

In 1990-2010, daily smoking varied largely between genders showing decreasing trend among men, but not among women. In 2010, one third of men and one fifth of women were daily smokers. Daily smoking was strongly associated with education among both genders. Trends of daily smoking prevalence by education during the study period and notably higher smoking among men with lower education in 1996-2010 and among women in 2002-2010 indicated that patterns of daily smoking in Estonia fit the model of tobacco epidemic in developed countries. At the same time, in 1990-2010, occasional smoking was stable and similar among men and women, and no relationship was found with education.

Educational differences in daily smoking highlight the importance of addressing smoking behaviour in the general population in Estonia by educational subgroups.

\section{Competing interests}

The authors declare that they have no competing interests.

\section{Authors' contributions}

KP: made a substantial contribution to the conception and the design of the study, interpretation of the data, drafted the manuscript and has been involved in revising the manuscript critically. MLP: participated in the design of the study, has been involved in statistical analysis, drafted the manuscript and has been involved in revising the manuscript critically. IR: performed statistical analysis, has been involved in the interpretation of the data and in revising the manuscript critically. MT: principal investigator of the study of Health Behaviour among Estonian Adult Population, was involved in the interpretation of the data and critically revised the manuscript. All authors read and approved the final manuscript.

\section{Acknowledgements}

The work was supported by the Estonian Ministry of Education and Research (target funding SF0180060s09) and by the Estonian Research Council grant PUT299. The survey Health Behaviour among Estonian Adult Population was funded by Estonian Ministry of Social Affairs, National Strategy for Prevention of Cardiovascular Diseases 2005-2020; supported by the Estonian Ministry of Education and Research (target funding 01921112 s02 and SF0940026s07)

\section{Author details}

'Department of Public Health, University of Tartu, Ravila 19, 50411 Tartu, Estonia. ${ }^{2}$ Estonian Cancer Registry, National Institute for Health Development, Hiiu 42, 10619 Tallinn, Estonia. ${ }^{3}$ Department of Epidemiology and Biostatistics, National Institute for Health Development, Hiiu 42, 10619 Tallinn, Estonia.

Received: 20 December 2013 Accepted: 2 July 2014

Published: 10 July 2014

\section{References}

1. WHO: Social determinants of health. The solid facts, 2nd edition. Copenhagen: WHO Regional Office for Europe; 2003.

2. Cavelaars AE, Kunst AE, Geurts JJ, Crialesi R, Grotvedt L, Helmert U, Lahelma E, Lundberg O, Matheson J, Mielck A, Rasmussen NK, Regidor E, do RosárioGiraldes M, Spuhler T, Mackenbach JP: Educational differences in smoking: international comparison. BMJ 2000, 320:1102-1107.

3. Giskes K, Kunst AE, Benach J, Borrell C, Costa G, Dahl E, Dalstra JA, Federico B, Helmert U, Judge K, Lahelma E, Moussa K, Ostergren PO, Platt S, Prättälä R, Rasmussen NK, Mackenbach JP: Trends in smoking behaviour between 1985 and 2000 in nine European countries by education. J Epidemiol Community Health 2005, 59:395-401.

4. Huisman M, Kunst AE, Mackenbach JP: Educational inequalities in smoking among men and women aged 16 years and older in 11 European countries. Tob Control 2005, 14:106-113.
5. Lopez AD, Collishaw NE, Piha T: A descriptive model of the cigarette epidemic in developed countries. Tob Control 1994, 3:242-247.

6. Muller A: Education, income inequality, and mortality: a multiple regression analysis. BMJ 2002, 324:23-25.

7. Graham H: Smoking prevalence among women in the European Community 1950-1990. Soc Sci Med 1996, 43:243-254.

8. Regidor E, Gutierrez-Fisac JL, Calle ME, Navarro P, Dominguez V: Trends in cigarette smoking in Spain by social class. Prev Med 2001, 33:241-248.

9. Platt S, Amos A, Gnich W, Parry O: Smoking policies. In Reducing inequalities in health: a European perspective. Edited by Mackenbach JP, Bakker MJ. London: Routledge; 2002:125-143.

10. Vedoy TF: The role of education for current, former and never-smoking among non-western immigrants in Norway. Does the pattern fit the model of the cigarette epidemic? Ethn Health 2013, 18:190-210.

11. WHO European health for all database (HFA-DB). http://data.euro.who.int/ hfadb/.

12. Schaap MM, Kunst $A E$, Leinsalu M, Regidor E, Espelt A, Ekholm O, Helmert U, Klumbiene J, Mackenbach JP: Female ever-smoking, education, emancipation and economic development in 19 European countries. Soc Sci Med 2009, 68:1271-1278.

13. Leinsalu $M$, Tekkel $M$, Kunst AE: Social determinants of ever initiating smoking differ from those of quitting: a cross-sectional study in Estonia. Eur J Public Health 2007, 17:572-578.

14. Schaap MM, Kunst AE, Leinsalu M, Regidor E, Ekholm O, Dzurova D, Helmert U, Klumbiene J, Santana P, Mackenbach JP: Effect of nationwide tobacco control policies on smoking cessation in high and low educated groups in 18 European countries. Tob Control 2008, 17:248-255.

15. Pärna K, Rahu K, Rahu M: Patterns of smoking in Estonia. Addiction 2002, 97:871-876.

16. Pärna K, Rahu K: Sotsiaal-majanduslikud erinevused suitsetamises: terviseuuring 2006. (Socio-economic differences in smoking in Estonia: Health Interview Survey 2006). Eesti Arst 2008, 88:57-62.

17. Centers for Disease Control and Prevention: Best practices for comprehensive tobacco control programs. Atlanta: Centers for Disease Control and Prevention; 2007

18. Main C, Thomas S, Ogilvie D, Stirk L, Petticrew M, Whitehead M, Sowden A: Population tobacco control interventions and their effects on social inequalities in smoking: placing an equity lens on existing systematic reviews. BMC Public Health 2008, 8:178.

19. WHO: Which are the most effective and cost-effective interventions for tobacco control? Copenhagen: WHO Regional Office for Europe; 2003.

20. Lipand A, Kasmel A, Kivilo M, Tasa E, Puska P, Berg M-A, Peltoniemi J: Eesti täiskasvanud elanikkona terviseuurimus 1990.a. kevadel. Health behaviou among Estonian Adult Population, Spring 1990. Helsinki: National Public Health Institute; 1991.

21. Lipand A, Kasmel A, Tasa E, Puska P, Berg M-A: Eesti täiskasvanud elanikkonna terviseuurimis 1992.a. kevadel. Health behaviour among Estonian Adult Population Spring 1992. Helsinki: National Public Health Institute; 1993.

22. Lipand A, Kasmel A, Tasa E, Leinsalu M, Uutela A, Puska P, Helakorpi S: Eesti täiskasvanud elanikkonna terviseuuring, kevad 1994. Health Behaviour among Estonian Adult Population, Spring 1994. Helsinki: National Public Health Institute; 1994:1995.

23. Kasmel A, Lipand A, Kasmel K, Traat U, Markina A, Uutela A, Helakorpi S, Puska P: Eesti täiskasvanud elanikkonna tervisekäitumise uuring, kevad 1996. Health Behaviour among Estonian Adult Population, Spring 1996. Helsinki: National Public Health Institute; 1996:1997.

24. Kasmel A, Lipand A, Kasmel K, Markina A, Prättälä R, Helasoja V, Puska P: Eesti täiskasvanud elanikkonna terviseuuring, kevad 1998. Health Behaviour among Estonian Adult Population, Spring 1998. Helsinki: National Public Health Institute; 1998:1999.

25. Kasmel A, Lipand A, Markina A, Kasmel K: Eesti täiskasvanud elanikkonna tervisekäitumise uuring, kevad 2000. Health Behaviour among Estonian Adult Population, Spring 2000. Tallinn: Estonian Centre for Health Education and Promotion; 2001

26. Kasmel A, Lipand A, Markina A: Eesti täiskasvanud elanikkonna tervisekäitumise uuring, kevad 2002. Health Behaviour among Estonian Adult Population, Spring 2002. Tallinn: Estonian Centre for Health Education and Promotion; 2003

27. Tekkel M, Veideman T, Rahu M: Eesti täiskasvanud rahvastiku tervisekäitumise uuring, 2004. Health behaviour among Estonian adult population, 2004. Tallinn: Tervise Arengu Instituut; National Institute for Health Development; 2005. 
28. Tekkel M, Veideman T, Rahu M: E: Eesti täiskasvanud rahvastiku tervisekäitumise uuring, 2006. Health behaviour among Estonian adult population, 2006. Tallinn: Tervise Arengu Instituut; National Institute for Health Development; 2007.

29. Tekkel M, Veideman T, Rahu M: Eesti täiskasvanud elanikkonna tervisekäitumise uuring, 2008. Health behaviour among Estonian Adult Population, 2008. Tallinn: Tervise Arengu Instituut; National Institute for Health Development; 2009

30. Tekkel M, Veideman T: Eesti täiskasvanud rahvastiku tervisekäitumise uuring, 2010. Health Behaviour among Estonian Adult Population, 2010. Tallinn: Tervise Arengu Instituut; National Institute for Health Developmen; 2011.

31. Eek F, Ostergren PO, Diderichsen F, Rasmussen NK, Andersen I, Moussa K, Grahn M: Differences in socioeconomic and gender inequalities in tobacco smoking in Denmark and Sweden; a cross sectional comparison of the equity effect of different public health policies. BMC Public Health 2010, 10:9.

32. Zatonski W, Przewozniak K, Sulkowska U, West R, Wojtyla A: Tobacco smoking in countries of the European Union. Ann Agric Environ Med 2012, 19:181-192.

33. Ahmad OP, Boschi-Pinto C, Lopez AD, Murray CJL, Lozano R, Inoue M: Age standardization of rates: a new WHO standard. Copenhagen: World Health Organization; 2001.

34. Vartiainen E, Seppälä T, Lillsunde P, Puska P: Validation of self-reported smoking by serum cotinine measurement in a community-based study. J Epidemiol Community Health 2002, 56:167-170.

35. Wong SL, Shields M, Leatherdale S, Malaison E, Hammond D: Assessment of validity of self-reported smoking status. Health Rep 2012, 23:47-53.

36. Korkeila K, Suominen S, Ahvenainen J, Ojanlatva A, Rautava P, Helenius H, Koskenvuo M: Non-response and related factors in a nation-wide health survey. Eur J Epidemiol 2001, 17:991-999.

37. Van Loon AJ, Tijhuis M, Picavet HS, Surtees PG, Ormel J: Survey nonresponse in the Netherlands: effects on prevalence estimates and associations. Ann Epidemiol 2003, 13:105-110.

38. Roberts B, Gilmore A, Stickley A, Rotman D, Prohoda V, Haerpfer C, McKee M: Changes in smoking prevalence in 8 countries of the former Soviet Union between 2001 and 2010. Am J Public Health 2012, 102:1320-1328.

39. OECD: Health at a glance: Europe 2012. Luxemburg: OECD Publishing; 2012. http://dx.doi.org/10.1787/9789264183896-en.

40. Finland's ASH (Action on Smoking and Health). In http://www.suomenash. fi/fin/in_english/.

41. Hiscock R, Bauld L, Amos A, Fidler JA, Munafo M: Socioeconomic status and smoking: review. Ann N Y Acad Sci 2012, 1248:107-123.

doi:10.1186/1471-2458-14-709

Cite this article as: Pärna et al:: Educational differences in cigarette smoking among adult population in Estonia, 1990-2010: does the trend fit the model of tobacco epidemic? BMC Public Health 2014 14:709.

\section{Submit your next manuscript to BioMed Central and take full advantage of:}

- Convenient online submission

- Thorough peer review

- No space constraints or color figure charges

- Immediate publication on acceptance

- Inclusion in PubMed, CAS, Scopus and Google Scholar

- Research which is freely available for redistribution 